\title{
Megabenthic gastropods in the outer Uruguayan continental shelf: composition, distribution and some effects of trawling
}

\author{
Gasterópodos megabentónicos en la plataforma continental exterior uruguaya: composición, \\ distribución y algunos efectos de la pesca de arrastre
}

\author{
Alvar Carranza ${ }^{1}$ y Sebastián Horta ${ }^{1}$ \\ ${ }^{1}$ UNDECIMAR, Facultad de Ciencias, Universidad de la República, Iguá 4225, CP11400, Montevideo, Uruguay \\ alvardoc@fcien.edu.uy
}

\begin{abstract}
Resumen.- Este estudio tuvo como objetivo profundizar el conocimiento de los efectos de la pesca de arrastre en los gasterópodos megabentónicos con concha, de la plataforma continental uruguaya. La composición, distribución de las especies, daños directo en la concha y mortalidad directa, así como la frecuencia de cicatrices en la concha fueron analizadas a partir de datos recolectados a bordo del barco de investigación ‘Aldebaran'. Un total de 12 especies de gasterópodos megabentónicos se registró en las 35 estaciones monitoreadas, tanto como especimenes vivos o como conchas vacías. De ellos, los gasterópodos con concha Adelomelon beckii, Adelomelon ancilla, Odontocymbiola magellanica, Fusitriton magellanicus y Zidona dufresnei dominaron numéricamente la captura incidental. Se observó una segregación espacial de las asociaciones de gasterópodos a lo largo de un gradiente batimétrico y latitudinal, con O. magellanica, F. magellanicus y $A$. ancilla ocurriendo en la porción sur del área de estudio, mientras que $A$. beckii y $Z$. dufresnei estuvieron restringidos a las áreas mas norteñas y someras, respectivamente. Raramente se observó mortalidad directa, pero las conchas de A. ancilla, $O$. magellanica y $Z$. dufresnei resultaron dañadas frecuentemente durante las operaciones de pesca y posterior procesamiento de la captura. De acuerdo con esto, se encontró una alta correlación positiva entre la frecuencia observada del daño reciente de la concha y la presencia de cicatrices, una evidencia sugerente pero no concluyente acerca de la relación entre la incidencia de cicatrices en la concha y la perturbación ocasionada por la pesca de arrastre.
\end{abstract}

Palabras clave: Efectos sub letales, Adelomelon, Odontocymbiola, Zidona, Fusitriton

\begin{abstract}
This study aims to advance knowledge on the effects of bottom trawling in the shelled megabenthic gastropods from Uruguayan continental shelf. Composition of by-catch, species distribution, direct shell damage and mortality, and frequency of repaired shell damage were analysed from data collected on board of the research vessel 'Aldebaran'. A total of 12 megabenthic gastropod species was registered from 35 stations surveyed, either as live specimens or empty shells. From these, the shelled gastropods Adelomelon beckii, Adelomelon ancilla, Odontocymbiola magellanica, Fusitriton magellanicus and Zidona dufresnei dominated numerically the by-catch. We observed a spatial segregation of the gastropod assemblages along a bathymetric and latitudinal gradient, with O. magellanica, F. magellanicus and A. ancilla occurring at the southern portion of the study area, whereas A. beckii and Z. dufresnei were restricted to the northern and shallower areas respectively. Direct mortality was barely observed, but shells of A. ancilla, O. magellanica and Z. dufresnei were frequently damaged during the fishing operation and capture handling. Accordingly, we found a high positive correlation between the observed frequency of recent shell damage and the presence of scars, suggestive but not conclusive evidence on the relationship between incidence of repaired shell damage and trawling disturbance.
\end{abstract}

Key words: Sub lethal effects, Adelomelon, Odontocymbiola, Zidona, Fusitriton

or injuries received following direct contact with the gear (de Groot 1984, Lindeboom \& de Groot 1998). In addition, discarded or damaged benthos may be rapidly consumed by opportunistic scavenger species, such as crabs, starfish and fish among others (Demestre et al. 2000, Kaiser \& Spencer 1994). In this context, the knowledge about the effects of the fishing array and onboard capture handling on particular non-target taxa is of particular interest, allowing a closer understanding on the impacts of trawling in the benthic community. 
In the south-western Atlantic shelf, shelled megabenthic gastropods are a conspicuous component of the benthic biota, due to their abundance and large size, some species reaching up to $40 \mathrm{~cm}$ in shell length. Despite the fact that the hake trawl fishery is among the most important fisheries in the Uruguayan shelf, the current knowledge of the discards generated by the fleet is limited, as well as on the possible impacts on megabenthic gastropod's populations (Carranza 2006). However, in shelled gastropods, sublethal effects can be evidenced by the presence on repaired skeletal injuries, an approach already validated for other ecosystems and species (Witbaard \& Klein 1994). The relative proportion of shells bearing scars is thus likely to be correlated with the degree of trawling disturbance. Therefore, the aim of this paper is twofold, first to shed light on the general qualitative and quantitative aspects of the by-catch of megabenthic gastropods, focusing in sublethal effects, and, finally, to explore the utility of the collected information regarding the assessment of trawling effects on the different species of gastropods.

\section{Material and methods}

The study area comprised a belt between the 50 and 300 isobaths of the Uruguayan continental shelf, and it is localized between the latitudes 34 and $37^{\circ} \mathrm{S}$ and longitudes 52 and $54^{\circ} \mathrm{W}$ (Fig. 1). It is characterized by a particular hydrographical system composed by water masses of contrasting thermohaline characteristics (i.e. confluence of Brazil and Malvinas currents) (Acha et al. 2004, Ortega \& Martínez 2007).

We registered the specific composition of megabenthic gastropods, direct mortality, degree of directly inflicted injuries and the frequency of repaired shell damage in both live specimens and empty shells. Observations came from 35 stations surveyed during a cruise of R/V 'Aldebaran' from the National Direction of Aquatic Resources (DINARA). Over each station, the trawling was held for 30 minutes at a mean speed of 3.5 knots, using an Engel type bottom trawl net with a $24 \mathrm{~m}$ horizontal opening and a $100 \mathrm{~mm}$ stretched mesh in the cod ends. Voucher material for gastropod species is

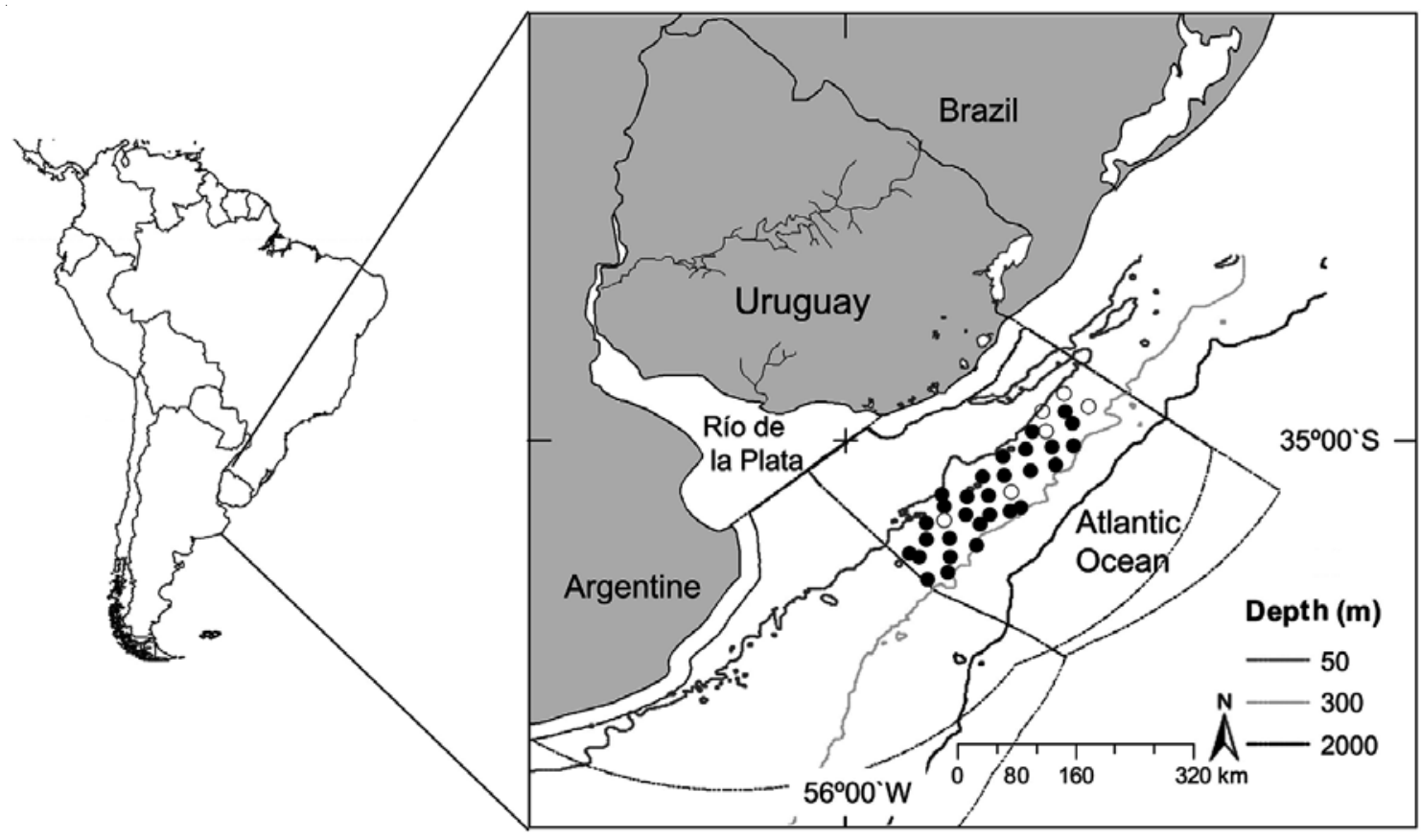

Figure 1

Study area showing the Uruguayan shelf, bathymetry and position of the surveyed stations. Presence of gastropod by-catch is shown by full circles

Área de estudio mostrando la plataforma continental uruguaya así como la batimetría y la ubicación de las estaciones muestreadas. La presencia de gasterópodos en la captura incidental se indica con círculos llenos 
deposited at Museo Nacional de Historia Natural of Montevideo.

Mean by catch per unit effort (BPUE) was calculated for all species ( $\mathrm{n}^{\circ}$ individuals 30' haul ${ }^{-1}$ ), taken only in consideration live animals. Multivariate analysis was carried out using PRIMER (Plymouth Marine Laboratory). Hierarchical agglomerative clustering was undertaken using group-average sorting of Bray-Curtis similarity coefficients calculated from BPUE/stations species data. Samples lacking live gastropods were not included in the analysis. For the assessment of frequencies of repaired shell damage (RSD) we considered all shells with external, macroscopically visible shell scars. Both scars and recently inflicted damage were classified following Alexander (1981), and Elliott \& Bounds (1987) as localized and severe damage. Significance of the relationship between the percentage of recent damage and frequency of repaired shell damage was assessed by means of ordinary least square regression (OLS), in order to examine the inter-specific consistency of the damage patterns. To this end, we performed a regression analysis between frequency of occurrence of recent damage and frequency of occurrence of repaired shell damage, each species being an independent observation. The species with the higher concordances are thus considered to be potentially good indicators of trawling disturbance.

\section{Results}

A total of 12 megabenthic gastropod species were registered from the 35 stations surveyed, either as live specimens or dead shells (Table 1). From these, the limpet Fissurellidea megatrema and at least one undetermined nudibranch, were not analyzed due to its particular anatomical features (i.e. loss or extreme reduction of the shell). Other shelled gastropods, collected only as dead shells (Trophon patagonicus and Pachycymbiola brasiliana) and the nassarid Buccinanops cochlidium (only one live specimen collected) were also excluded from the condition analysis. With the exception of $T$. patagonicus, both species are typical inhabitants of inner shelf areas (Carranza et al. 2008a).

We observed a spatial segregation of the gastropod assemblages along the latitudinal and bathymetric gradients, with $O$. magellanica, F. magellanicus and $A$. ancilla occurring at the southern portion of the study area, $Z$. dufresnei occurring mainly at the shallower stations, whereas T. galea and $A$. beckii were restricted to the northernmost portion. Accordingly, cluster analysis discriminated two main groups of stations: group 1 comprised $\mathrm{N}$ stations characterized by the presence of $O$. magellanica, F. magellanicus and A. ancilla, while $Z$. dufresnei, A. beckii and F. megatrema characterized group 2. One station (station 11) did not cluster on any group, due to the only record of T. galea (Fig. 2).

\section{Table 1}

Number of observations (n), mean, standard deviation (S.d.) and maximum BPUE (ind $x$ tow $^{-1}$ ) (Max.), and percentages of empty shells, live specimens with observed recent damage and with scars of repaired shell damage for each species

Número de observaciones (n), media (Mean), desviación típica (S.d.) y CIPUE máxima (ind x lance ${ }^{-1}$ ) (Max.), y porcentajes de conchas vacías, especimenes vivos con daños recientes observados y con presencia de cicatrices en la concha para cada especie

\begin{tabular}{lrlccccc}
\hline Species & $\mathrm{n}$ & Mean & S.d. & Max. & $\begin{array}{c}\text { \% Empty } \\
\text { shells }\end{array}$ & $\begin{array}{c}\text { \% Damaged } \\
\text { shells }\end{array}$ & $\begin{array}{c}\text { \% Repaired } \\
\text { shell damage }\end{array}$ \\
\hline BC & 1 & 0.03 & 0.2 & 1.0 & 0.0 & 0.0 & 0.0 \\
TG & 35 & 0.03 & 0.2 & 1.0 & 97.1 & 0.0 & 5.7 \\
AB & 8 & 0.22 & 0.6 & 3.0 & 0.0 & 12.5 & 0.0 \\
ZD & 22 & 0.36 & 1.2 & 5.0 & 4.3 & 52.4 & 31.8 \\
OM & 29 & 0.61 & 1.2 & 4.0 & 34.5 & 47.4 & 37.9 \\
FUM & 27 & 0.64 & 2.7 & 16.0 & 7.4 & 4.0 & 0.0 \\
FIM & 41 & 1.14 & 3.3 & 17.0 & 0.0 & 0.0 & 0.0 \\
AA & 80 & 1.22 & 3.9 & 21.0 & 16.3 & 25.4 & 18.8 \\
\hline
\end{tabular}

AB: Adelomelon beckii, AA: Adelomelon ancilla, OM: Odontocymbiola magellanica, FUM: Fusitriton magellanicus, TG: Tonna galea, ZD: Zidona dufresnei, BC: Buccinanops cochlidium and FIM: Fissurellidea megatrema 


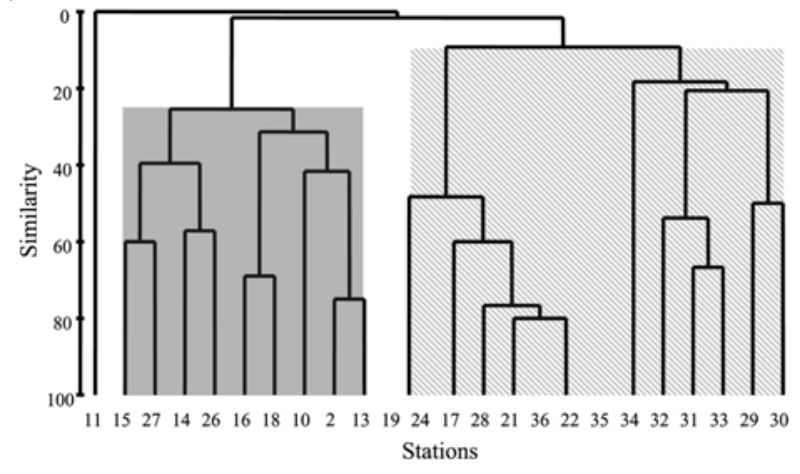

Figure 2

Dendrogram showing the results of the hierarchical agglomerative clustering of stations (Bray-Curtis similarity index) based on biological data (BPUE) and spatial distribution of the groups discriminated by the analysis

Dendrograma mostrando los resultados del agrupamiento jerárquico aglomerativo de las estaciones (índice de similitud de Bray-Curtis) basadas en datos biológicos (CIPUE) y distribución espacial de los grupos discriminados por el análisis

In terms of BPUE (abundance of live collected specimens only), the volutid Adelomelon ancilla $(n=67)$ dominated the gastropods by-catch, followed by the ranelid Fusitriton magellanicus $(\mathrm{n}=25)$ and the volutids Zidona dufresnei $(\mathrm{n}=21)$ and Odontcymbiola magellanica $(\mathrm{n}=19)$. From 201 examined shells, we found that $97.3 \%$ of Tonna galea, 34\% of O. magellanica and $19 \%$ of $A$. ancilla shells were empty or occupied by hermit crabs.

Overall, $13 \%$ of the measured shells had some rupture, with trimmed lips and broken necks accounting mostly of the localized damage. Direct damage was observed in nearly $50 \%$ of $O$. magellanica and more than $50 \%$ in $Z$. dufresnei (see Table 1 for details). Nature of shell damage differed between species: in $Z$. dufresnei the more frequent lesions were broken apex (36\%) and trimmed lips (73\%), whereas A. ancilla showed $93 \%$ of trimmed lips, $25 \%$ of broken necks and only $6 \%$ of apical lesions. In O. magellanica, $22 \%$ of the specimens measured were severely crushed, causing most likely a direct mortality. The species-specific frequencies of scars indicating RSD were positively and significantly correlated with the frequency of onboard shell damage $\left(\mathrm{R}^{2}=0.88 ; P<0.05\right)$.

\section{Discussion}

To date, no other study has focused on the impact of trawling on the molluscan assemblage of the outer Uruguayan shelf. We found that 12 gastropod species may be potentially affected by trawling. Carranza (2006) already reported the by-catch of some of the species here treated (A. ancilla, O. magellanica and F. magellanicus) in a survey made onboard a commercial fishing vessel operating at the northern Argentinean shelf. The species we observed at the southern portion of our study area are mostly representative of the Magellanic malacofauna, whereas at the northern stations were representative of the shallow or warm-temperate malacofauna (T. galea, A. beckii and $Z$. dufresnei). This remarks the existence of a faunal transition zone localised off Río de la Plata (see Fig. 1) coincident with the Brazil-Malvinas currents confluence, that is presumably acting as a barrier for some benthic species inhabiting the continental shelf (Carranza et al. 2007, Carranza et al. 2008b).

Direct mortality was barely observed caused by aggressive handling but we noticed $22 \%$ of $O$. magellanica with severe damage. In addition, Malaquias et al. (2006) suggested that while the time discarded species spend on board may be not long enough to cause direct death by anoxia or dehydration, mortality may occur as a consequence of barotraumatism, thermal trauma, predation in the water column, predation during the post-settlement period while the animal is recovering or adapting, or from settling on unsuitable substratum. All these factors were unexplored in the present work, but its potential negative effects must be taken into consideration. Estimates of instant mortality rates based on the ratio live animals/dead shells were not calculated due to uncertainty about the timing of shell degradation.

The observations made on damage patterns in live shells indicated that species more prone to get injured while handling were also those that presented a higher proportion of RSD; as found in other studies (Carranza 2006). The volutid species here analyzed (A. ancilla and O. magellanica) were more prone to suffer direct shell damage while onboard handling, with the exception of the largest species (A. beckii), while F. magellanicus did not show any apparent injury. The injuries may also be caused after discarding, since damaged benthos may attract predators and scavengers (Groenewold \& Fonds 2000), further altering the natural proportion of damaged and undamaged shells. In this study it was assumed that repaired shell damage was a result of trawling inflicted damage. However, the incidence of scars in live shells may also indicate unsuccessful predation attempts, making it harsh to separate naturally inflicted damage from those caused by onboard handling or later release. Nevertheless, the direct evidence for predation upon large shelled gastropods at the study area is scarce, shelled gastropods seem to be absent from the dietary composition of likely predators, as the Patagonian skate Bathyraja macloviana (Scenna et al. 2006), although anecdotic evidence suggest the incidence of $O$. 
magellanica and $A$. ancilla in the diet of unidentified Batoideans (F Scarabino pers. com. ${ }^{1}$ ). We suggest that $A$. ancilla and $O$. magellanica are suitable species to be used as indicators of fishing disturbance, due to the fact that: a) they are abundant; b) they are frequently damaged onboard; and c) they show a high frequency of RSD, suggesting survival after trawling. Both species occur at the southern portion of the study area, but extends its distribution south to the Magellan strait reaching also the Pacific Ocean. For the above reasons, both species are suitable to direct research efforts along a wide geographical area.

\section{Conclusions}

Several species of gastropods are likely to be affected negatively by bottom trawling, but the degree of the effect varies among species and areas. Sublethal effects were evident in all the volutid species, with the exception of A. beckii. We encourage further studies on this subject, explicitly examining damage patterns in the gastropods shells, to see if there is any systematic pattern possibly caused by fisheries. To this end, it would be desirable to separate predation-induced scars from those caused by trawling. In the absence of direct information (e.g. video surveys) that allows quantifying the degree and effects of trawling disturbance, the use of the information stored in the gastropods shells may be a valuable tool. Quantitative assessments of the by-catch of non-targeted species are strongly encouraged.

\section{Acknowledgments}

The field work was done with the kind collaboration of the 2006-07 crew of the R/V ‘Aldebaran'. Financial support from CSIC of the Universidad de la República, PEDECIBA and ANII (Uruguay) to the authors is acknowledged. A. C. also thanks Marina and Estela for support. Special thanks to F. Scarabino for providing valuable suggestions and relevant bibliography. Three anonymous reviewers helped to improve the manuscript.

\section{Literature cited}

Acha EM, HW Mianzan, RA Guerrero, M Favero \& J Bava. 2004. Marine fronts at the continental shelves of austral South America: Physical and ecological processes. Journal of Marine Systems 44: 83-105.

Alexander RR. 1981. Predation scars preserved in Chesterian brachiopods: probable culprits and evolutionary

\footnotetext{
${ }^{1}$ Fabrizio Scarabino, Museo Nacional de Historia Natural y Antropología, Montevideo, Uruguay; Dirección Nacional de Recursos Acuáticos, Montevideo, Uruguay
}

consequences for the articulates. Journal of Paleontology 55:192-203.

Alves F, L Chicharo, A Nogueira \& J Regala. 2003. Changes in benthic community structure due to clam dredging on the Algarve coast and the importance of seasonal analysis. Journal of the Marine Biological Association of the United Kingdom 83: 719-729.

Badino G, F Bona, A Maffiotti, O Giovanardi \& P Fabio. 2004. Impact of mechanical clam harvesting on a benthic habitat: evaluation by means of sediment profile imaging. Aquatic Conservation: Marine and Freshwater Ecosystems 14: 559-567.

Bergman MJN \& JW van Santbrink. 2000. Mortality in megafaunal benthic populations caused by trawl fisheries on the Dutch continental shelf in the North Sea in 1994. ICES Journal of Marine Science 57: 1321.

Carranza A. 2006. Large gastropods by-catch in the hake fishery at the Argentinean-Uruguayan common fishing zone. Comunicaciones de la Sociedad Malacológica del Uruguay 9: 61-67.

Carranza A, F Scarabino, L Ortega \& S Sauco. 2007. Geographic and bathymetric distribution of Americominella duartei (Neogastropoda: Buccinidae), a bathyal species from the Southwestern Atlantic. Pan-American Journal of Aquatic Sciences 2: 255-260.

Carranza A, F Scarabino \& L Ortega. 2008a. Distribution of large benthic gastropods in the Uruguayan continental shelf and Río de la Plata estuary. Journal of Coastal Research 24: 161-168.

Carranza A, F Scarabino, A Brazeiro, L Ortega \& S Martínez. 2008b. Assemblages of megabenthic gastropods from Uruguayan and northern Argentinean shelf: Spatial structure and environmental controls. Continental Shelf Research 78: 788-796.

de Groot SJ. 1984. The impact of bottom trawling on benthic fauna of the North Sea. Ocean Management 9: 177-190.

Demestre M, P Sánchez \& MJ Kaiser. 2000. The behavioural response of benthic scavengers to otter-trawling disturbance in the Mediterranean. In: Kaiser MJ \& SJ de Groot (eds) Effects of Fishing on Non-target Species and Habitats, pp. 121-129. Blackwell Scientific Publications, Oxford.

Elliott DK \& SD Bounds. 1987. Causes of damage to brachiopods from the Middle Pennsylvanian Naco Formation, central Arizona. Lethaia 20: 327-335.

Groenewold S \& M Fonds. 2000. Effects on benthic scavengers of discards and damaged benthos produced by the beam-trawl fishery in the southern North Sea. ICES Journal of Marine Science 57: 1395-1406.

Jennings S, TA Dinmore, DE Duplisea, KJ Warr \& JE Lancaster. 2001. Trawling disturbance can modify benthic production processes. Journal of Animal Ecology 70: 459-475. 
Kaiser MJ \& BE Spencer. 1994. Fish scavenging behaviour in recently trawled areas. Marine Ecology Progress Series 112: 41-49.

Lindeboom HJ \& SJ de Groot. 1998. IMPACT-II. The effects of different types of fisheries on the North Sea and Irish Sea benthic ecosystems. NIOZ - Rapport 1998 (1). Netherland Institute for Sea Research: Den Burg Texel: 1404.

Malaquias MAE, L Bentes, K Erzini \& TC Borges. 2006. Molluscan diversity caught by trawling fisheries: a case study in southern Portugal. Fisheries Management and Ecology 13: 39-45.

Ortega L \& A Martínez. 2007. Multiannual and seasonal variability of water masses and fronts over the Uruguayan shelf. Journal of Coastal Research 23: 681-629.
Philippart CJM. 1998. Long-term impact of bottom fisheries on several by-catch species of demersal fish and benthic invertebrates in the south-eastern North Sea. ICES Journal of Marine Science 55: 342-352.

Probert KP, DG Mcknight \& SL Grove. 1997. Benthic invertebrate bycatch from a deep-water trawl fishery, Chatham Rise, New Zealand. Aquatic Conservation: Marine and Freshwater Ecosystems 7: 27-40.

Scenna LB, SB García de la Rosa \& JM Díaz de Astarloa. 2006. Trophic ecology of the Patagonian skate, Bathyraja macloviana, on the Argentine continental shelf. ICES Journal of Marine Science 63(5): 867-874.

Witbaard R \& R Klein. 1994. Long-term trends on the effects of southern North Sea beam trawl fishery on the bivalve mollusc Arctica islandica L. (Mollusca, Bivalvia). ICES Journal of Marine Science 51: 99-105.

Recibido el 6 de junio de 2007 y aceptado el 14 de febrero de 2008 